〔第43回総会シンポジウム〕

\title{
6.インビボ核医学の動向と医療技術者の役割
}

\author{
星 野 光 雄
}

東邦大学医学部付属大橋病院 放射線部

Key words: In vivo, Immuno nuclear medicine, Technologist education

\section{THE STATUS, ON THE PRESENT-TO-FUTURE OF IN VIVO NUCLEAR MEDICINE AND THE ROLE OF MEDICAL TECHNOLOGISTS}

\author{
Mitsuo Hoshino \\ Department of Radiology, Tohho University Medical School, Ohhashi Hospital
}

\section{Summary}

Physiological and biochemical studies and whole-body research on diseases of unknown incidence lesions, which are presently being universal studied for all organs will be studied continuous for practical application.

Future studies may consist of (1) research in the physipathological mechanism regarding cranial nerves diseases using neurotransmitters, (2) Immuno-nuclear medicine and (3) clearing the causes for incurable diseases. Those studies may be practical used through the use of feed back from positron nuclear medicine to single photon nuclear medicine.

Future nuclear medicine will be supported by basic studies such as clinical physipathology, cytology, immunology, pharmacology, and embryology.

\section{1.はじめに}

近代技術は画像検査法の多様化をもたらした。エネル ギー源はX線や $\gamma$ 線のほか陽電子線, 可視光, 超音波, 磁気など電離非電離の別なく広汎に及ぶ.しかし，これ らを核医学技法と核医学以外の技法（他法）とに分け， それら技法が成立するための根元的要素と得られる情報 内容とを考えると, 核医学技法のみ別で, 他法は殆んど 共通していることが解る。すなわち，技法構成要素にあ っては核医学が薬剂, 装置, 検查技術の三つからなるの に対し，他法は装置と検査技術が基本であるほか情報内 容も核医学が生理・病理情報であるのに対し，他法は形 態情報が主体である。

拠って著者は今後動向を決定する最大の要素は, 核医 学におき薬剤, 他法にあっては装置と考え, この観点か
らインビボ核医学の今後動向とそれを支えるため必要な 医療技術者, 特に診療放射線技師の技術知識につき論述 する。

\section{2. 検査内容および方法の動向}

今後動向は, 他法では不可能であるも核医学的には可 能な絶対適応，他法との相関性ないし特定ケースに抢き 対象となる相対適心，および近未来での可能性を予測し た将来適応，この三つに区分し述べる．なお，この区分 に含まれる各検查項目は，一般的な日常臨床用を中心と したものであるが，例外としサイクロトロン製剤につい てもふれる。

\section{1 絶 対適 応}

絶対適応には大きく分け, (1)発生個所の不明および不 定疾患の全身検索，(2)各臓器それぞれの生理学的・病理 

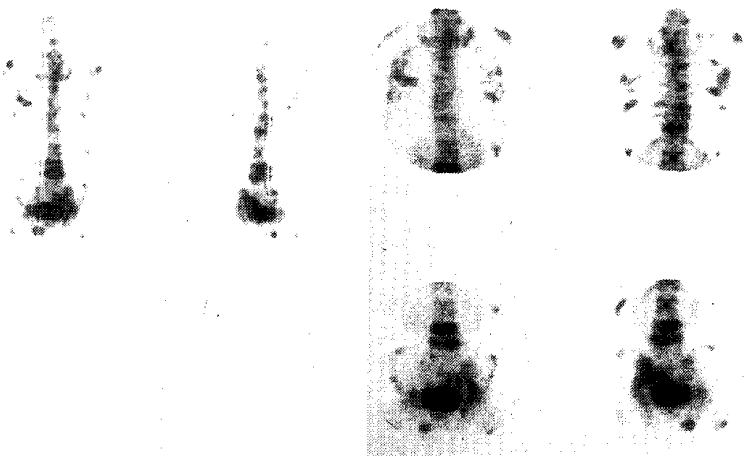

Fig. 1 リン酸剤による転移巣検索

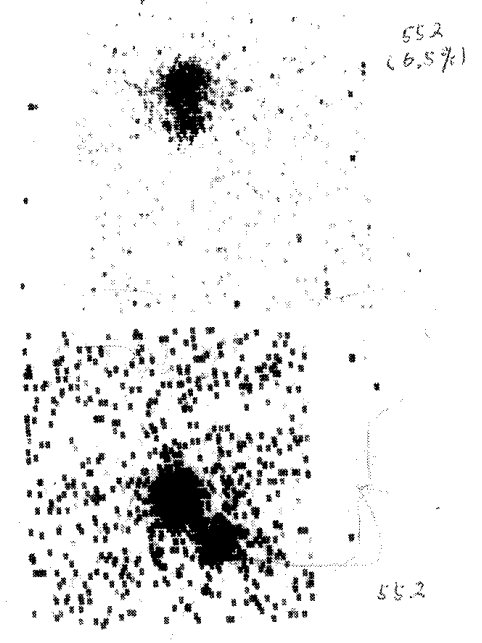

Fig. 2 異所 (舌根部) 甲状腺像
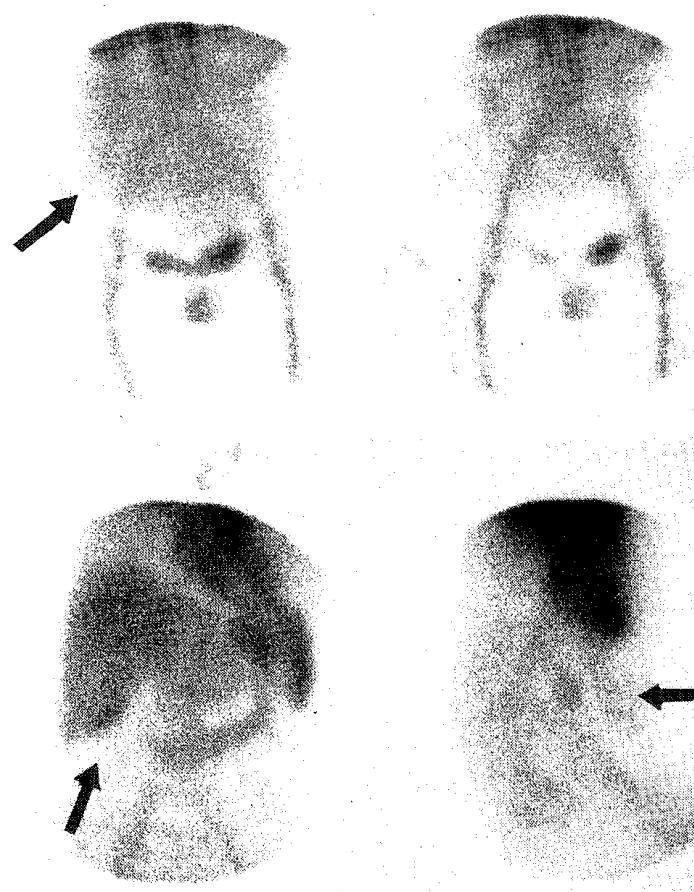

Fig. 3 消化管出血例
学的形態㧍よび機能検索, (3)ヨード過敏症者への適応, この 3 群が考元られる．核医学技法注ど簡単に全身検索 可能な方法は他になく，(1)では腫瘍巣や炎症栄の検索， 異所性組織の存在確認, 出血巣扝よび体液漏出個所の検 索, 等がある (Fig. 1, Fig. 2, Fig. 3).

Fig. 1 はDP (Methylen di-phosphnate)を用いた前 立腺癌患者の術後例である。癌検索ではこのリン酸㓮と 並び，ほか最も多用されるものにガリウムもあり，前者 が骨組織を目的とするのに対し, 後者は軟部組織を対象 とする.Fig. 2 はコードが所定 (頸) 部に集積せず，舌根 部に集積した例である。舌根部甲状腺が検出できた。 Fig. 3 は， ${ }^{99 m} \mathrm{~T} \mathrm{c}$ 標識赤血球にて行った消化管出血の 2 例で ある。上段は下腹部に広く出血血液が広がり下段では, 空腸に出血巣が存在していた。

(2)の生理的病理的機能検査では画像を伴うものと，伴 わないものとの両方が可能である. 画像を伴う例には交 換能 (肺ガス), 攝取能 (甲状腺・副腎), 排池能 (尿 胆汁・唾液), 循環能 (血液・リンパ液) 等があり, 画像 を伴わない例では鉄代謝, 循環赤血球量や血漿量, 赤血 球寿命およびビタミン $\mathrm{B}_{12}$ 吸収試験等がある.

Fig. 4 は急に息苦しくなり,救急入院した例である.胸 部X線と核医学検查を行い，X線で異常なかったが，核

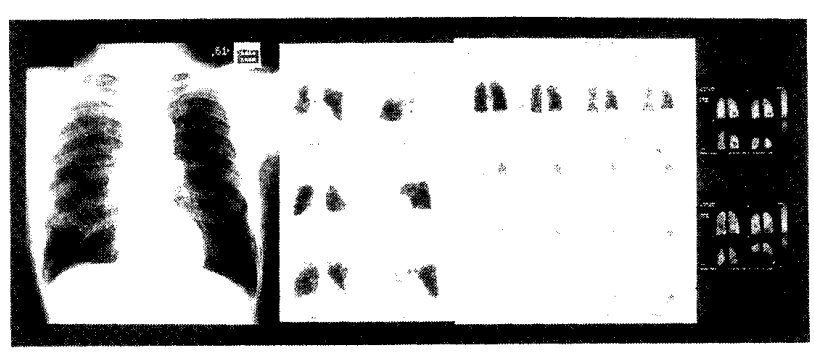

胸部X線

肺血流

肺換気

Fig. 4 閉塞性肺疾患例

医学では肺血流と換気に明らかな障害を認め, 肺硬塞と 診断された。(3)は，説明不要と考元省略する。

\section{2 相 対適応}

核医学技法とは, RI を追跡子とするトレーサ検査法と 定義できるし，生きてる状態の検査法でもある。したが って適応の相対性は他法の特街や, 各技法の成熟度に依 存するものの例えば核医学技法の体液にあっては, 流れ る方向や速さ，量など容易に検索できる。この例では心 臓や脈管系の血液循環があり, 脳脊䯣液の流れもある。 また脳でも, 血液脳関門生理機構の破壊巣は本法で直接 検出できるし, 虚血性脳疾患に対しては ${ }^{123} I-I M P(N$ - 


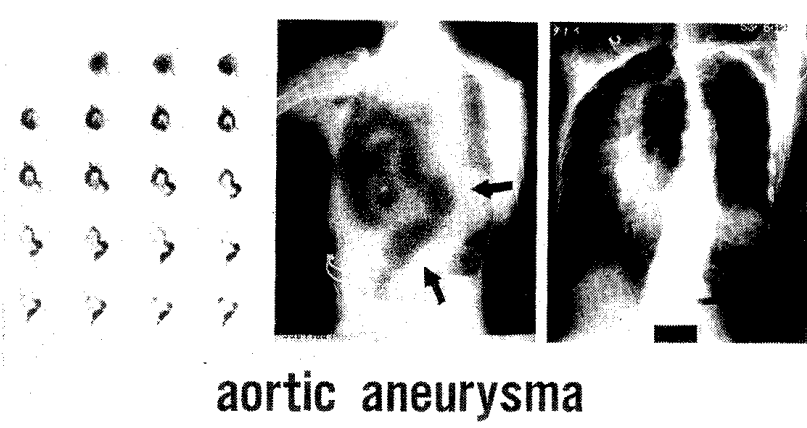

Fig. 5 胸部大動脈溜

isopropyl-p [ $\left.{ }^{123} \mathrm{I}\right]$ iodo an phetamine) の有効例が数多 w.

Fig. 5 は,胸部大動脈瘤の例である.われわれはこれら のほか, 核医学技法の特徵を生かし起立性低血圧症の検 索にも役立てている。

つまり絶対的あるいは相対的に適応されるもののうち， 呼吸器疾患や循環器疾患, および出血や体液漏出など, 救急医療に役立つものは決して少なくない.

以上は全てシングルフォトンであった。これに対し施 設設備やマンパワー等との相対性で適応となるものに， ポジトロン核種がある。それにはジェネレータで抽出可 能なものとサイクロトロンで製造するものとがあり，サ イクロトロン製造核種 ${ }^{21}$ に蛋白, 脂質, 糖質など生体構 成必須元素が多い（Table 1)。したがって，それを使え ば生体機構や薬物代謝を定量的に動態観測できるほか，
癌の質的診断や組織別診断も可能となる。しかし実用的 には膨大な費用と人材が必要であり, 設置・運用は特定 機関に限定される。拠ってその社会的役割は，シングル

Table 1 サイクロトロン製造核種とその検査薬(例)

\begin{tabular}{|c|c|c|c|}
\hline 核種 & 半減期 & 無機ガス体，標識化合物 & 応 用 \\
\hline${ }^{11} \mathrm{C}$ & 20 分 & 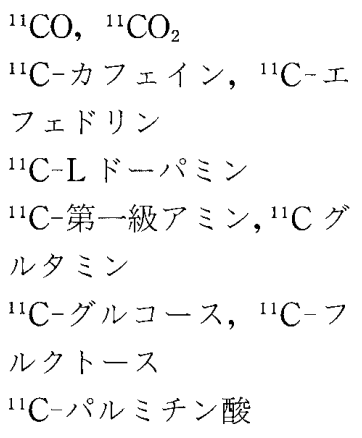 & $\begin{array}{l}\text { 肺血流機能 } \\
\text { 脳, 副腎 } \\
\text { 脳機能 } \\
\text { 肝機能 } \\
\text { 糖尿病 } \\
\text { 心筋 }\end{array}$ \\
\hline${ }^{13} \mathrm{~N}$ & 10分 & $\begin{array}{l}{ }^{13} \mathrm{~N} \text { アミノ酸 } \\
{ }^{13} \mathrm{NH}_{3}\end{array}$ & $\begin{array}{l}\text { 心筋, 脳, 肝 } \\
\text { 肝, 心臓, 膵 }\end{array}$ \\
\hline${ }^{15} \mathrm{O}$ & 2 分 & $\begin{array}{l}{ }^{15} \mathrm{O}_{2}, \mathrm{C}^{15} \mathrm{O}, \mathrm{C}^{15} \mathrm{O}_{2} \\
{ }^{15} \mathrm{O}_{2}-\text { アルコール, }{ }^{15} \mathrm{O}_{2}- \\
\text { アルデヒド }\end{array}$ & $\begin{array}{l}\text { 肺血流機能 } \\
\text { 循環器系 }\end{array}$ \\
\hline${ }^{18} \mathrm{~F}$ & 10分 & 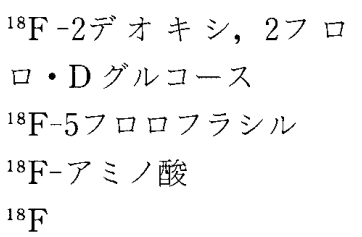 & $\begin{array}{l}\text { 脳代謝機能 } \\
\text { 腫瘍 } \\
\text { 膵蛋白代謝 } \\
\text { 骨 }\end{array}$ \\
\hline
\end{tabular}

Table 2 将来適応の薬剤例(1986年現在)

\begin{tabular}{|c|c|c|}
\hline & 対象・方 法 & 薬 \\
\hline \multirow[t]{2}{*}{$\begin{array}{l}レ \\
セ \\
\rightarrow 0 \\
\text { タ }\end{array}$} & 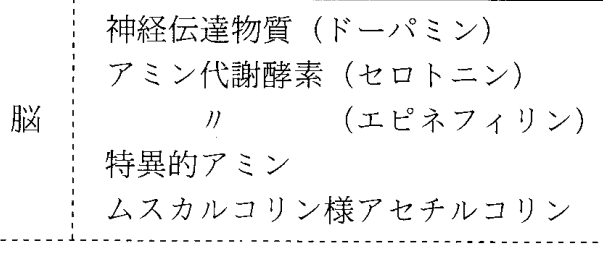 & $\begin{array}{c}{ }^{123} \mathrm{I}-\mathrm{ISP} \\
{ }^{123} \mathrm{I}-\mathrm{MIL} \\
{ }^{123} \mathrm{I}-\mathrm{MIBG} \\
{ }^{123} \mathrm{I}-\mathrm{HIPDM},{ }^{99 \mathrm{~m}} \mathrm{Tc}-\mathrm{NEP} \\
{ }^{123} \mathrm{I}-\mathrm{IDEX},{ }^{123} \mathrm{I}-\mathrm{IQNB}\end{array}$ \\
\hline & エストロゲン & ${ }^{123} \mathrm{I}-\mathrm{EST}$ \\
\hline $\begin{array}{l}\text { 心 } \\
\text { 筋 }\end{array}$ & $\begin{array}{l}\text { 硬 塞 } \\
\text { 脂肪酸代謝 } \\
\text { 血 流 }\end{array}$ & $\begin{array}{c}{ }^{99 \mathrm{~m}} \mathrm{Tc}-\mathrm{MIBI},{ }^{99 \mathrm{~m}} \mathrm{Tc}-\mathrm{MPI} \\
{ }^{123} \mathrm{I}\left({ }^{131} \mathrm{I}\right)-\text { 高級脂肪酸 } \\
{ }^{99 m} \mathrm{Tc}-\mathrm{TBI}\end{array}$ \\
\hline 肝 & $\begin{array}{l}\text { アシアロ糖蛋白 } \\
\text { 解離イオン反応 }\end{array}$ & $\begin{array}{l}{ }^{99 m} \mathrm{Tc}-\mathrm{NGA} \\
{ }^{62} \mathrm{Zn}-\mathrm{EDDA}\end{array}$ \\
\hline 膵 & アミノ酸代謝 & ${ }^{123} \mathrm{I}-\alpha$-メチルチロシン \\
\hline 癌 & $\begin{array}{l}\text { 神経芽細胞腫 } \\
\text { 䯣様癌 }\end{array}$ & $\begin{array}{c}{ }^{123} \mathrm{I}-\mathrm{QNB} \\
{ }^{99 \mathrm{~m}} \mathrm{Tc}-\mathrm{DMS}(\mathrm{V}),{ }^{99 \mathrm{~m}} \mathrm{Tc}-\mathrm{DMSA}\end{array}$ \\
\hline モ & ローナル抗体 (MAb) の金属錯体 & ${ }^{111} \mathrm{In} \cdot{ }^{99 \mathrm{~m}} \mathrm{Tc} \cdot{ }^{67} \mathrm{Ga} \cdot{ }^{123} \mathrm{I}, \quad-\mathrm{MAb}$ \\
\hline
\end{tabular}


フォトン核医学の水先案内を果すとともに, シングルフ オトン核種への成果環元にあると考えてよい.

\section{3 将来適応}

将来適応の殆んどは，核医学技法の本質に照らし，シ ングルフォトン製剤と考え間違いなく，ここでは動物実 験ないし臨床治験段階に至ったうち特に有望と考えるも のを示した（Table 2).

脳の虚血性疾患では, ${ }^{99 m} \mathrm{Tc}-\mathrm{HM}-\mathrm{PAO}$ (hexamethylpropyleamine oxine) を用いた臨床例 ${ }^{3), 4}$ がすでにあり， 画像は ${ }^{123} I-I M P よ り$ 鮮明化する筈である、脳ではほか， レセプ夕伝達物質や代謝酵素等5)での検索も可能となり, 神経伝達系の機構解明が行われるであるう。これと並ん で大きいもう一つが，癌の検索である。CEA やAFP, CA19-9 など, 癌関連抗原のモノクローナル抗体 ${ }^{6}$ にに標 識した製剂では国内でも臨床応用がなされており，国外 的には褐色細胞腫に対する ${ }^{123} \mathrm{I}^{-} \mathrm{MIBG}^{7}$ ) (meta iodoben- zyl guanidine）の有効例に加え, 神経芽細胞腫や䯣様癌 など, 癌の組織別診断も進みつつある，その他，心筋や 肝，膵についても，Table 2 の例8),9) が考えられる.

\section{3. 今後の検査を支える技術者}

\section{1 現行の在学教育}

インビボ核医学は現在, 殆んどの施設におう, 技術分 野は診療放射線技師（放射線技師）が支えている。した がって，将来に対するその技術知識基盤を確認するため， 教育カリキュラムを調查した（Table 3).

Table 3 に示す学科のうち, 看護, 放射線, OT・PT が東京都立医療短期大学のカリキュラム ${ }^{10)}$ で, 臨床検查 は他校のそれである。これより学科ごと科目内容を比較 すると, 放射線学科においては理工系科目が多いのに対 し, 他の学科では医療医学や生物系が多い。また, 医療 従事者の養成機関に対しては文部省または厚生省が，そ

Table 3 医㙩技術者の在学教育(専門系)カリキュラム

\begin{tabular}{|c|c|c|c|c|c|c|c|c|c|}
\hline & \multicolumn{2}{|l|}{ 看 } & \multicolumn{3}{|l|}{ 護 } & \multicolumn{2}{|l|}{ 臨 床 檢 査 } & 放 射 線 & $\mathrm{OT} \cdot \mathrm{PT}$ \\
\hline 薬 & & 理 & & & 学 & 実 験 用 動 物 & 学 & 放 射 線 生 物 学 & 理 \\
\hline 微 & 生 & & 物 & & 学 & 微生物 & 学 & 放 射線 衛 生 学 & 救 急 及 び 消 \\
\hline 衛 & 生 & & 法 & & 規 & 関 & 規 & 係 & 生 \\
\hline 社 & 会 & 福 & 补 & & 論 & 臨 床 病 理 学 総 & 論 & 放 射 線 医 学 概 論 & 社 会 福 祉 \\
\hline 人 & 間 & & 工. & & 学 & 剖 組 織 & 学 & $\mathrm{X}$ 線 解 剖 & 職業倫理 - 職場管理学 \\
\hline 臨 & 床 & 心 & 理 & & 学 & 人 & 学 & 応 & 床 心 理 学 \\
\hline 内 & 科 & 系 & 医 & & 学 & 医用動物 学(含むs実 & 習) & 放 射 線 物 理 学 & 放 射 線 医 学 概 論 \\
\hline 外 & 科 & 系 & 鸟 & & 学 & 臨 床 検 查 学( & ) & 放 射 線 化 & 看 護 学 概 論 \\
\hline 小 & 牢 & & 医 & & 学 & 臨 床 生 理 学( & ) & 子 計 算 & 小 巟 科 学 概 論 \\
\hline 母 & 性 & & 医 & & 学 & 臨 床 化 学( & ) & 像 工 & 老人 科 学 概 論 \\
\hline 精 & 神 & & 知 & & 学 & 臨 床 血 清 学( & ) & 原 子 $工$ 学 概 論 & 言 語 治 療 学 概 論 \\
\hline 放 & 射 線 & 医 & 学 & 概 & 論 & 学( & ) & 医 用 工 学 概 論 & 理 学 治 療 学 概 論 \\
\hline 看 & 護 & 学 & 根 & & 論 & 臨 床 免 疫 学( & ) & 放 射 線 技 術 学 特 論 & リハビリ医学(含む演猊) \\
\hline 看 & 護 & 学 & 特 & & 論 & 臨床微生物学( & ) & 超 音 波検 查技術学 & 職能適性管理学（／）） \\
\hline 看 & 護 & & 技 & & 術 & 病理組織細胞学( & ) & 放 射 化 学(含む実験) & 運 動 学(含む演習・実習) \\
\hline 成 & 人 看 & 護 & 学 & 概 & 論 & RI 検 查 技 術( & ) & 電 気 工 学( & 作 業 療 法 学 $(n)$ \\
\hline 成 & 人 & & 保 & & 健 & 医用電子工学概論 $(\quad n$ & ) & 電 子 工 学( & 作業療法技術学 $(n)$ \\
\hline 老 & 人 & & 保 & & 健 & 化 & 習 & 自動制御工学( & 身体障害作業療法学（ $/ 1)$ \\
\hline 小 & 览 & & 保 & & 健 & 病 & 習 & 放射線機器工学( & 精神障害作業療法学 $(n)$ \\
\hline 母 & 性 & & 保 & & 健 & 細 胞 組 織 学 実 & 習 & 写 真 工 学( & 発達障害作業療法学（）） \\
\hline 成 & 人 看 & 護 & 学 & 特 & 論 & 微 生 物 学 & 習 & 放射線計測学( & 日常生活能分析学 $(n)$ \\
\hline 老 & 人 看 & 護 & 学 & 特 & 論 & 公 衆 衛 生 学 実 & 猊 & X線撮影技術学(含屯実習) & 補 \\
\hline 女 & 性 看 & 護 & 学 & 特 & 論 & 検 査 管 理 & 論 & RI 検查技術学( $川$ & 作 業 療 法 研 究 法 \\
\hline 成 & 人看護 & 学 & （含す & 吅実方 & & 検 査 機 器 総 & 論 & 放射線治療学( & \\
\hline 地 & 域 看 護 & 学 & & $n$ & ) & & & 文 & \\
\hline 小 & 北看 護 & 套学 & & n & ) & & & & \\
\hline 母 & 性 看 護 & 锆 学 & & 11 & ) & & & & \\
\hline 総 & 合 & & 実 & & 習 & & & & \\
\hline
\end{tabular}


の最低限必要なカリキュラムを義務づけていることから， この事実は他校にあっても大同小異と考える.

\section{2 放射線技師の役割}

医療ニーズについては，検査内容および方法の動向の 項で概説した。その他可能性のあるものでは未だ治療法 の確立してない疾患，いわゆる難病の検索や解明への用 途が考えられる（Table 4).

Table 4 難病 (厚生省指定中の例)

\begin{tabular}{|c|c|}
\hline 1.ベーチェット病 & 15. 天疱瘡 \\
\hline 2.スモン病 & 16. 啨髄小脳変性症 \\
\hline 3.多発性硬化症 & 17.クローン病 \\
\hline 4 .重症筋無力症 & 18. 劇症肝炎 \\
\hline 5 .全身性エリテマトーデス & 19.悪性関節リューマチ \\
\hline 6.再性不良性賓血 & 20.パーキンソン病 \\
\hline 7.サルコイドーシス & 21.アミロイドーシス \\
\hline 8.筋委縮性側索硬化症 & 22. 後縦靭带骨化症 \\
\hline 9 .強皮症 & 23.ハンチントン舞踏病 \\
\hline 10.特発性血小板減少性紫斑病 & 24.ウェゲナー肉芽腫症 \\
\hline 11. 結節性動脈周囲炎 & 25. 特発性拡張型心筋症 \\
\hline 12. 潰瘍性大腸炎 & 26.シャイ・ドレガー症候群 \\
\hline 13. 大動脈炎症候群 & 27.モヤモヤ病(ウィリス動脈錀閉塞症) \\
\hline 14.ビュルガー病 & 28.表皮水疱症 \\
\hline
\end{tabular}

Table 4 は，厚生省が治療法の研究を指定した特定疾 患であり，難病にはこの活癌やエイズ，メニエール病 等，治る見込みの少ないものや無いもの，および末だ病 名さえ無いものなど, 数多く存在するのは周知の通りで ある、したがってこれらに対し核医学技法がどれだけ貢 献できるか，否，画像検查法の総力を上げてもどれだけ 寄与できるかは，われわれ放射線技師の大命題と言えよ う.

\section{3 現在および今後必要な技術知識}

“チーム医療”の言葉が使われ始めて久しい. しかし， 名実ともに実行するためには，隣接スタッフの技術知識 が広く相互乗り入れ可能でなければならず，この点で放 射線学科の科目は医療医学の基礎におき, 他学科に比し 少なかつた。すなわち，装置操作者とし理工系科目が重 要なことは勿論である。だが，医学は生物学の一分野と 考えるし，医療とは患者と術者，いわゆる人間対人間の 対応でもあるため，適確な情報収集には，医療医学の理 解が伴わねばならない. したがってこの見地より放射線 技師が補完す心゙き学習課題を提示した（Table 5).

医療人とし体得すべき課題は，年令層・精神状態を含 め病める者への対処法であり，この点は放射線技術全般
Table 5 放射線技師の学習課題

\begin{tabular}{|c|c|}
\hline 医療 人 & 核医学検査技術 \\
\hline 人 間 工 学 & 細 胞 工 学 \\
\hline M E 工 学 & 細 胞 学 \\
\hline 医 療 倫 理 & 解剖 組織学 \\
\hline 老人医学 & 人体発生学 \\
\hline 小巟医学 & 臨床生理学 \\
\hline 神 経 医 学 & 臨床病態学 \\
\hline 臨 床心理学 & 臨床病理学 \\
\hline 救急 ・ 消毒法 & 臨床薬理学 \\
\hline の & そ の 他 \\
\hline
\end{tabular}

に共通する，また，核医学検査技術にあってはこれに加 え, 医学・生物学系に扔ける基礎の充実が重要と考える.

\section{4. 考察・まとめ}

画像検査の魅力は, 多種のエネルギー源を生体画像化 に結びつけた，それら一つ一つは急速に進展し，成果は 日ならずして医療現場に導入される。しかしその本質に おき, 生理機能や病理機構の画像化可能な方法は他にな く, 今後これに続く可能性のあるのは MRIのみである.

多様な画像化は一エネルギー源によっても可能な今日, 放射線技師教育での理工系科目の豊富さは, 時宜を得て いる，だが，核医学技術に関する限り，必要条件ではあ っても充分条件とは言い難い. その理由は, 核医学技法 の三大構成要素に薬剤が存在するからである。そのほか, これまでの核医学は主として理工学の進歩に依存し発展 して来た。だが今後発展の鍵は, 薬学生物学が握ると考 えるからである。な扔，モノクローナル抗体の患者投与 についてひと言補足すると，それはその特性より考え， 実施利用に先立ち, 適応上の院内的な医療倫理確立が前 提，ということである.

また，患者と直接的に接する作業は，殆んどの施設が 放射線技師と考える. したがって，放射線技師がインビ ボ核医学の将来につき責務を抱くは, 極めて重要である. しかし身分法では，人体への放射線照射を業とするのが 放射線技師である，インビボ業務の技師はこの点が異な り，人体から放出の放射線を用いて検査する。拠ってわ れわれは末来を目ざして技術知識の研鑽に励むとともに， 身のまわりをしっかり見つめる努力も急ってはならない.

\section{文献}

1）日本メジフィジックス，IMP別刷集 I， II

2）樫原昌夫，他：日本製鋼所技報， 41，(2-4).

3) RA Holmens, et al. : NMC6, 443-447, (1985). 
4) PF Sharp, et al.: JNM, 27(2), 171-177.

5) 飯尾正宏: 島津医用機器二ュース, 41, 2-4, (1983).

6）有吉 寛：映像情報，16(13)，695-702，（1984）。

7) Donald M, Wieland, et al.: JNM 21(4), 349-353.
8) Furn F, Knapp, et al.: JNM, 27(4), 521-531.

9）久保田佳嗣, 他：核医学, 23(7), (899-904).

10）東京都立医療技術短期大学 昭和 61 年度学生募集要 項. 